\title{
Blended Learning to Improve University Students' Language Skills in the Iraqi Context
}

\author{
Hero Said Mohammed Nuri , and Hanife Bensen Bostanci \\ A \\ Department of Translation Techniques, Erbil Technical Administrative Institute, \\ Erbil Polytechnic University, Kurdistan region of Iraq \\ ${ }^{b}$ Department of English Language Teaching, Near East University, Near East \\ Boulevard, PK: 99138, North Cyprus, Mersin 10 Turkey
}

Article History: Received: 11 January 2021; Accepted: 27 February 2021; Published online: 5 April 2021

\begin{abstract}
This study investigated the effect of a blended learning approach (BLA) on the main English language skills (listening, speaking, reading, writing) when learning English as a foreign language (EFL) in Iraq. In order to reveal the effectiveness of the approach, an experiment was carried out involving 40 participants who were divided into two groups: experimental and control. The experimental group was taught using a BLA whereas the control group was instructed with a traditional approach to teach English. The experiment was conducted during a semester (three months) in which two classes of English were taught every week. According to the results of the study, the BLA had a dramatic effect on improving the main skills of the EFL participants.
\end{abstract}

Keywords: difficulty Blended Learning Approach; Foreign Language Learning; Attitudes;Language skills; Main Skills.

\section{Introduction}

Language is continually changing and is a creative phenomenon (Yule, 2016). Traditional approaches, used to teach a language in a single class, are difficult because learners have different levels of English proficiency. In other words, some learners may learn and comprehend more quickly than others.Nazzal (2014) explains that traditional classroom means a lack of collaboration and grouping, and transferring information from the teachers to the students as well as a teacher-centered classroom. Thus, traditional classroom instruction alone may not be sufficient to suit the individual needs of the learners. Consequently, a more modernized innovative approach that serves the individual needs of the learners should be utilized in the language learning classroom. Educators should convey their information to the learners by resorting to a motivating and innovative approach. For that end, the blended learning approach is one of the approaches that provide this opportunity.

Due to the use of traditional approaches at schools in the northern region of Iraq, students are still struggling with pronunciation and the four fundamental skills (listening, speaking, reading, and writing), no technological devices are employed such as CD players. One of the reasons of that outcome could be attributed to not having students being grouped in relation to their level of English proficiency; students are grouped in one class regardless of their level of English proficiency. Consequently, traditional teaching approaches are used in the classrooms where little consideration is given to the learners. For this reason, it is of vital importance to adopt a method that will overcome these issues in the English as a foreign (EFL) classroom.

In the light of study problem, this study seeks to answer the following question:

1. What are the effects of employing a blended learning approach on the main skills (listening, speaking, reading and writing) of second-year English as a foreign language learner in Iraq?

The study aims at pinpointing the benefits of the blended learning approach (BLA) when teaching EFL by revealing its impact on students' learning of English in the context of the study. Thus, the following thesis targets probing the advantages (if any) of the approach under investigation. Taking into account the above objectives. To the best of my knowledge, this study will be the first to reveal the effect of a BLA in the Northern part of Iraq. Consequently, this study is essential in that it endeavors:

\section{Literature Review}

EFL learners face challenges not only when they are planning to study abroad but also when they publish academic texts and/or when interpreting concepts in the English language (Nielson \& González-Lloret, 2010). The cultural and social behaviour and perspectives become the biggest challenges for the English as a foreign language (EFL) learners when they want to explain and convey their actual thoughts and ideas (Cook \&Artino, 2016). The English language skills are increasingly demanding in the world, and being an academic language, it has become significant for the young generation to learn, speak and develop their skills in the English language (Mak\&Coniam, 2008). The English language skills are not only needed for academic purposes but also while seeking a bright career in multinational corporations worldwide. Hence, ignoring the English language proficiency is ignorance to a better future in the modern world of competitiveness (Kashefi, Ismail, \&Yusof, 2012).

\section{Traditional Learning}

The traditional method of teaching foreign languages is when a teacher directs students to learn through memorize many grammatical rules and exceptions as well as extensive vocabulary lists and recitation techniques thereby not developing their critical thinking problem solving and decision-making skills. The aim of this method 
is to enable students to read and translate literary and classical masterpieces (Prince \& Felder, 2006). Traditional method is based largely on a reduction of the integrated process of using a foreign language into sub-sets of discrete skills and areas of knowledge. It is largely a functional procedure which focuses on skills and areas of knowledge in isolation. Following on from this, traditional methodologies are strongly associated with the teaching of language which is used in a certain field related to the students' life or work (Boumová, 2008). Traditional methods donot use CD players, projectors and any technological tool. It is solely based on the usage of a marker and a whiteboard.

Traditional learning can be defined as the kind of learning which depends basically on textbooks while the modern methods rely on a hands-on materials approach (Brooks \& Brooks, 1999). Furthermore, in traditional learning, materials are presented firstly with the parts and then the movement is made to the whole; in the modern approaches, the presentation is the other way round. Moreover, the concentration is laid on the separate skills in the traditional method whereas big concepts or ideas are highlighted more in modern methods. Assessment in the traditional classroom is separate from learning and occurs through testing while it is seen as an activity integrated with teaching and learning in the modern approaches, and occurs through portfolios and observation (Brooks \& Brooks, 1999).

According to what is mentioned above, classrooms which use traditional teaching are not very interesting because of the knowledge in general and the specific methods of teaching that include books and texts that do not suit the interests of all students together (Miyazoe\& Anderson, 2010). The learners have different interests and different preferences. Therefore, there should be different techniques and different approaches to serving individual interests. Effective teaching is fundamental to effective learning and learners (Klimova, 2009). Teaching and learning a foreign language has many challenges which are accelerated when the L2 learners have never been exposed to the L2 before. A study conducted by Adas and Bakir (2013) revealed that teaching English to Arab students is certainly challenging. It was noted in the study that the Arab students made more errors and that the traditional teaching activities were not much helping when it was related to minimizing these errors for effective teaching. Therefore, following these traditional teaching activities would result in submissive and monotonous classrooms. Dull and boring classrooms will rarely interest the learners and will impact negatively on the learning process. On the contrary, teaching an L2 requires new and innovative approaches, interactive techniques, enhanced engagement, lively discussions, and autonomy (Gopalan, Bakar, Zulkifli, Alwi, \& Mat, 2017).

\section{Blended Learning}

The blended learning approach (BLA) is an integrated instructional approach that combines face to face interactions within the classroom and online activities (Dziuban, Hartman, \&Moskal, 2004). The approach enables teachers to plan a lecture that will be interesting, engaging and fun for the students. Topics are prepared using creative multimedia tools and presented through the online medium and classroom sessions to engage students in interactive activities like discussions, debates, oral presentations and the clarification of queries. Schedules are flexible and convenient as students can access online content at any time (Garrison \&Kanuka, 2004). Luna and Winters (2017) said that teachers should decide and allow the content that has to be taught in class and through the online medium. For example, components like an introduction to a class, presentations, question and answer sessions, etc. are better-presented face-to-face whereas components like course information, quizzing, etc. may be presented online. Thus, they need to follow the standards of online courses that include the formulation of course objectives, content outline and inclusion of appropriate instructional techniques. Garrison and Kanuka (2004) explained that the BLA almost always involve students discussing questions and solving problems in class active learning, with much of the work in and out of the class being done by students working in groups (collaborative or cooperative learning).

The blended learning approach (BLA) is a popular and growing concept. It is common for enhancing the ability and capability of L2 learners. Blended learning has a prominent role in English language learning and English language teaching. It is not only essential for the learners but it also makes it easy for teachers to deliver the best possible environment to accelerate the learning process (Behjat, Yamini, \&Bagheri, 2012). The BLA refers to face-to-face and computer-based learning activities for improving the listening, speaking, reading and writing skills of the EFL learners (Jee\& O'Connor, 2014). BLA is the most adequate and authentic approach that can improve language learning skills. Thus, it is empirically evident to improve the language skills of L2 learners. The integration of face-to-face learning with the offline computer-based teaching and learning is evident for achieving high performance among the L2 learners. L2 learners often find it difficult to learn an L2, and it is also difficult to achieve high proficiency. However, with BLA, the EFL classrooms are more interactive and can impact the performance and achievement of EFL learners in learning the target language (e.g. Shih, 2010; Kashefi; Ismail, \&Yusof, 2012).

The EFL learners often experience difficulties in learning a new language. Learning a language is never easy even if it is not the L2 of the learner (Caruso, Colombi, \& Tebbit, 2017). It requires competency and consistency to enhance language skills, not only the reading and writing skills but also listening and speaking. The L2 learners may not be able to learn easily through the traditional approaches or within the traditional face-to-face learning classrooms. The BLA has played a vital role as a driver for performance and high achievement among the learners which has been empirically tested and has been made evident (López-Pérez, Pérez-López, \& Rodríguez-Ariza, 2011). Therefore, employing a BLA is essential for the improvement of L2 competency. 
English language teaching is hard with traditional face-to-face approaches and requires modern technological tools that are implemented in blended learning to achieve and maintain learner motivation. A study conducted by Shih (2010) revealed that blended learning requires instructor's feedback, self-reflection and interesting/updated material with a consistent revision to maintain satisfaction and motivation among learners. The learning process through blended learning cannot be successful without these principles. Self-directed and selfregulated learning is successful with effective teaching and efficient teaching environments. The material and curriculum play equally important roles to attain high quality and sustainable learning process (Wu, Tennyson, \& Hsia, 2010).

Blended learning helps in achieving learner's satisfaction and motivation that contribute to having a sustainable learning process (Ituma, 2011). The BLA is a flexible and interactive learning approach that helps in increasing student motivation, satisfaction, and performance. BLA promotes motivation in the learning process (Gopalan, Bakar, Zulkifli, Alwi, \& Mat, 2017). A study conducted by Henrie, Bodily, Manwaring, and Graham (2015) revealed that blended learning promotes and enhances student engagement and motivation. The learners in blended learning experience more freedom and the sessions are more flexible which attracts and involves learners in the learning process that the traditional learning approach does not (Su, Zheng, Liang, \& Tsai, 2018). The study further revealed that the learning outcomes and student motivation also improved while incorporating these techniques in the learning process. The BLA is very effective and poses a positive relationship between the learning outcomes and the learning motivation of the learning (Behjat, Yamini, \&Bagheri, 2012).

A study conducted by Isiguzel (2014) investigated the impact of blended learning on the motivation and success of EFL learners. The researcher conducted the study among 3rd-year students majoring in tourism and hotel management program. An experimental study was conducted to analyze the impact of the blended learning environment in enhancing motivation and success of the learners. The results of the study revealed that the experiment group learning through blended learning was more motivated and successful as compared to students learning through the traditional method. The researcher concluded that if there are motivation and success among learners learning through the traditional method, the activities conducted in the classroom revolve around the teacher rather than the learners. Thus, it can be concluded that blended learning has a significant and positive impact on the overall performance and has positive responses from teachers and learners. The blended approach to learning is useful for personalizing learning and meeting students' needs as it enables thoughtful reflection among learners, and the interaction among the diverse students promotes learning progressively (Lim \& Morris, 2009). As an illustration about that, a study conducted by Liu and Cha (2010) revealed that the learners of the English language have different motivation and the distinctive motivation of the learners are responsible for their selection of distinctive learning strategies within a blended learning environment.

\section{BLAfor Reading Skills}

A study conducted by Schechter, Macaruso, Kazakoff, and Brooke (2015), found that blended learning was effective in improving the reading skills of the learners. The study revealed that blended learning helped in improving the reading comprehension of the low socio-economic students of grade 1 and 2 . Blended learning helps in improving the reading skills of L2 learners because they get more opportunities for autonomous and selfregulated learning. Reading skills are multi-faceted and require a strong grip on comprehension (Behjat, Yamini, \& Bagheri, 2012). The reading skills are the optimal outcome of effective learning and teaching (Ghazizadeh, \& Fatemipour, 2017). Blended learning promotes reading skills because it involves international instructional techniques for reading in addition to having activities to promote reading traits and tactics. A study conducted by Zarei and Abdi (2016) outlined that blended learning promotes critical thinking skills among L2 learners as they read a lot and more specifically about the subject area of their interest. The study concluded that the integration of the computer promotes better reading skills and an ability to develop more analytical and critical thinking for logical reasoning.

In a study conducted by Ghazizadeh and Fatemipour (2017) blended learning was found to be effective for the reading proficiency of the L2 learners. The study was conducted among Iranian EFL learners through a Primary English Test (PET). The study revealed that there was a significant change in the reading proficiency of Iranian EFL learners. Thus, the study concluded that blended learning has the ability to accelerate the learning outcomes and especially the reading skills of L2 learners. Blended learning is a comprehensible source and substantial input for the learning process and English language learning in particular. Similarly, a study conducted by Behjat, Yamini, and Bagheri (2011) among 107 Iranian students revealed that reading comprehension with the help of a blended learning environment can yield effective results in the classrooms. Moreover, the online information available on the internet helps in building learner motivation for reading more and reading consistently. The learners in traditional learning are not open to more knowledge as that of blended learning. Books, material, and syllabi are limited and learners rarely get a chance to read on the updated information since books are not revised daily (Behjat, Yamini, \& Bagheri, 2011).

\section{BLA for Writing Skills}

The BLA is equally effective to improve the writing skills of EFL learners. A study conducted by Keshta and Harb (2013) among the Palestinian tenth graders revealed that blended learning can help improve the writing skills of the L2 learners. Writing skills in the L2 is important not just for scholarly/academic pursuits but also creativity.A BLA was found to have a better effect on students' writing performance in a study conducted by Bostanci and Cavusoglu (2018). The writing performances of the learners were significantly better when a BLA 
approach was adopted compared to pen-and-paper work. Both online and pen-and-paper modes of teaching writing were effective. However, the online writing mode with a BLA was better comparatively speaking. The writing skills, although hard to develop, could be made easier with the integration of modern tools and technology with improved visual and face-to-face sessions to motivate and inspire the learners to boost their academic and non-academic writing abilities (Mak\&Coniam, 2008).

A study conducted by Ghahari and Ameri-Golestan (2013) revealed that applying blended learning techniques for teaching students of the L2 improves the writing performance and comprehension skills of the learners with effective teaching. Acquiring writing skills in a L2 is often difficult and L2 learners face difficulty in interpreting language. The study concluded that blended learning helps in creating and promoting a learning environment that is desirable and important for EFL learners writing skills.Similarly, a study conducted by Fidaoui, Bahous, and Bacha (2010) found that blended learning for language learning in the Lebanese elementary writing of English in the ESL classrooms had remarkable outcomes in terms of performance and achievement. The BLA has much higher performance outcomes as compared to the traditional learning environment. The writing skills of the L2 learners were observed to improve a lot more than traditional learners. The use of the Internet and computer had bizarre and outstanding learning outcomes that signify blended learning for improving writing skills and writing abilities of the L2 learners.

The study of Geta and Olango (2016) whose sample consisted of 40 males and 10 female university learners pinpointed that "university instructors should willingly restructure their programs, courses and assessment to procedures to host BL" (p. 49) since it had a positive effect on the writing performance of the participants. In another study by Keshta and Harb (2013), blended learning was employed to enhance students writing abilities and a positive outcome was attained as the two researchers recommended that teachers and educators "adopt the blend in teaching English, hold educational courses and workshops for teachers in employing blended learning to enrich the teaching-learningprocess, create effective learning environment that enhances self- learning and develops students' achievement level" (p. 208). Similarly, a BLA was also found to be effective in a study by Wahyuni (2018) who carried out a study to "know the effect of blended learning model towards students' writing ability of the eleventh-grade students" (p. 97). Significant differences between the two groups before and after the treatment were found. The results indicated that the blended learning model positively affected students'

\section{BLA for Speaking Skills}

A study conducted by Miyazoe and Anderson (2010) revealed that improved writing skills from blended learning can also improve the speaking skills of L2 learners. The study observed that blogs, forums, and wiki in an EFL blended learning environment can help in improving the speaking skills of L2 learners.Blended learning is one of the most effective and reliable approaches to improve the speaking skills of L2 learners. The BLA allows the learners to interact with English native speakers that provide an opportunity for L2 learners to improve their proficiency and fluency in the L2 (Nielson \& González-Lloret, 2010). A study conducted by Jee and O'Connor (2014) revealed that BLA has virtual sessions and foreign instructors. Therefore, the learners are more focused on speaking the L2 rather than the first language (L1). The studyconcluded that the BLA helps in enhancing the proficiency and aptitude of the L2 learners and improves their speaking skills. Speaking the target language with native speakers allows the learners to improve their accent, pronunciation, fluency and get a strong command over the foreign language (Kavaliauskienè, 2011).

Furthermore, BLA was found to be effective in speaking in a study by Sánchez and Chavarro (2017) who found that the BLA was effective in EFL oral skills. As a matter of fact, the researchers found the approach positively impacting the students' different speaking skills as the findings indicated having a speaking performance showing high "use of vocabulary, use of body language, pronunciation and intonation patterns, production of chunksof language, monitoring oral production and, motivation and engagement" (Sánchez \&Chavarro, 2017, p.263).

\section{BLA for Listening Skills}

The BLA effectively focuses on all four skills and allows the learners to improve not just reading, writing and speaking but most importantly the listening skills as well (Kavaliauskienè, 2011). The listening skills are often neglected in traditional EFL classrooms (Dimitrios, Labros, Nikolaos, Maria, \& Athanasios, 2013). Listening is an important skill to acquire in a foreign language. A study conducted by Caruso, Colombi, and Tebbit (2017) revealed that blending learning effective for the development and assessment of the listening skills among L2 learners. The study observed that blended learning helps in improving the listening and speaking skills of L2 learners. The study observed that the online quizzes, test practices, and auditory material help L2 learners to practice the language in a native accent. This helps in understanding the words, their sounds, pronunciation, and their appropriate use. The study focused on a systematic analysis through an online student survey to analyze the effect of the online quizzes on the listening skills of the learners. Thus, it was concluded that the online quizzes significantly improved the listening skills and oral abilities of the learners.

A study conducted by Kavaliauskiene (2010) revealed that blended learning is effective for the teaching of listening to English for Specific Purposes (ESP). The study observed that although 40 percent of the daily communication is based on listening, it is not given much significance in terms of the improvement in the traditional classroom.A study conducted by Liu and Chu (2010) observed that using universal games in English language learning classrooms to improve the listening and speaking skills are one of the effective ways observed in blended learning. The study observed that the listening skills of the learners were significantly improved with 
these games and learning activities. Similarly, incorporating these activities also resulted in a positive and significant change in the overall receptive skills of the learners.

Accordingly, it could be seen that different studies have outlined that blended learning is important for the teaching of English to L2 learners. Blended learning is an approach that incorporates not just modern but some of the traditional teaching activities to promote a blended environment for accelerating and augmenting effective and efficient learning. The approach is used on different levels and has yielded equally significant results for high performance and high achievement among learners (Broadbent, 2017).

\section{Methodology}

\section{Research Design}

This study adopted an experimental research design to collect and analyze the data. Experimental design can be defined as a research design which "directly attempts to influence a particular variable" (Fraenkel, Wallen, Norman, \& Hyun, 2012, p. 265). It was, resorted to this approach since a treatment variable (the blended approach) was administrated among the samples. The design, in specific, followed a pre-/post-test design since an experiment was carried out: a pretest was carried out before the treatment, and posttest was carried out after the implementation of the blended learning approach (BLA) in order to reveal the effectiveness of the BLA approach. The pre-/post-test were prepared of four sections. Both the pre and posttest the same test was used before and after the experiment.

Quasi-experimentalresearch which is an empirical interventional study was employed to estimate the causative impact of an intervention on the target population without random assignment(Dinardo, 2008). The quasi-experimental design was employed as it helps in analyzing the impact of independent variables on a dependent one and it also helps in analyzing the change(s) that occur(s) in the dependent variable due to the administration of an independent variable (Fraenkel, Wallen, Norman, \& Hyun, 2012). Two groups of English learners studying English as a foreign language from the second year in the Department of Translation Techniques at Erbil Polytechnic University (EPU) in the Kurdistan Region of Iraq participated in this study. The participants were divided into two groups, namely, experimental and control. Grouping the participants was carried out by means of a proficiency test which was administrated among the participants, and then they were grouped according to their proficiency levels to avoid possible bias in our results among groups when be compared. It should be noted that the proficiency test was used to group the participants. In the end, both groups consisted of 20 EFL learners; so, in total there were 40 EFL learners. Both groups shared the same curriculum. The study was carried out in the new academic year of 2018 in the Fall semester which lasted for 14 weeks.

\section{Reliability and Validity}

To demonstrate the reliability of the scores given by the researcher, a second rater with ten years of teaching experience was chosen to score the writing sections of the test in order to assess the inter-rater reliability of the scores given. The scores of both the researcher and the teacher were placed onto a table below (see Table 1). It is evident from the table that both raters scored the writing sections approximately the same. There is a significant positive correlation between the marks of the pretest researcher and pretest teacher records, $(\mathrm{r}(40)=.88, \mathrm{p}<.00)$. Similar results were seen for the posttest scores given by both the researcher and teacher, $(\mathrm{r}(40)=.95, \mathrm{p}<.00)$. This suggests that the results are to a great extent reliable. It should be noted that the other three skills of reading, speaking and listening were not double checked by the second rater because all the questions were multiplechoice questions (see Appendix D).

Table 1

Reliability Scores of the Researcher and Teacher

\begin{tabular}{|c|c|c|c|}
\hline & & $\begin{array}{l}\text { Pretest/Researcher' } \\
\text { s marks }\end{array}$ & $\begin{array}{l}\text { Pretest/Teacher's } \\
\text { marks }\end{array}$ \\
\hline \multirow{3}{*}{$\begin{array}{l}\text { Pretest/Researcher's } \\
\text { marks }\end{array}$} & Pearson Correlation & 1 & $.887 * *$ \\
\hline & Sig. (2-tailed) & & .000 \\
\hline & $\mathrm{N}$ & 40 & 40 \\
\hline \multirow{4}{*}{ Pretest/Teacher's marks } & Pearson Correlation & $.887 * *$ & 1 \\
\hline & Sig. (2-tailed) & .000 & \\
\hline & $\mathrm{N}$ & 40 & 40 \\
\hline & & $\begin{array}{r}\text { Posttest/ Researcher's } \\
\text { markers }\end{array}$ & $\begin{array}{l}\text { Posttest/Teacher's } \\
\text { marks }\end{array}$ \\
\hline \multirow{4}{*}{$\begin{array}{l}\text { Posttest/ Researcher's } \\
\text { marks }\end{array}$} & Pearson Correlation & 1 & $.957 * *$ \\
\hline & Sig. (2-tailed) & & .000 \\
\hline & $\mathrm{N}$ & 40 & 40 \\
\hline & Pearson Correlation & $.957 * *$ & 1 \\
\hline Posttest/Teacher's & Sig. (2-tailed) & .000 & \\
\hline marks & $\mathrm{N}$ & 40 & 40 \\
\hline
\end{tabular}

**. Correlation is significant at the 0.01 level (2-tailed).

\section{Participants and Sampling}

The sample of the study consisted of 40 students studying in the Department of Translation Techniques at one of public university in Iraq. The participants were second-year students. The participants were both genders (male 
and female) between the ages of 18-22 years old, and they were Kurdish native speakers learning English as a foreign language (EFL). The researcher used a convenience sampling method which is a "type of nonprobability or nonrandom sampling where members of the target population that meet certain practical criteria, such as easy accessibility, geographical proximity, availability at a given time, or the willingness to participate are included for the purpose of the study" (Etikan, Musa, \&Alkassim 2016, p. 2).

\section{Data Collection}

A pre-test and a posttest were employed by the researcher. The aim of the pretest was to check the English proficiency level of the students so that the students with the same proficiency level could be included in the study. The researcher conducted a posttest after the experiment was completed to check the impact of the BLA. The difference between the scores of the pretest and the posttest were collected to evaluate the performances of the experimental and control groups before and after the implementation of the BLA. Posttest, the copiesof the language skills of the posttest, which is midterm exam of the experimental and control groups, were collected to compare the results in order to reveal the effectiveness of the BLA in learning the language skills. Posttest (the midterm exam) had four sections; The pre-test and the post-test consisted of multiple choice questions and short definitions which were all 23 points in the first section. The second section consisted of multiple choice questions to test the listening skills of the participants; all out of 20 marks. The 22 points of the third section consisted of comprehension texts to test the reading skills of the participants. Lastly, section four was designed to test the writing skills of the participants. Section four consisted of three comprehension essay questions where each question was 10 points, total points for all skills were 95 marks, and remain five marks for a quiz. According to the university's grading system, passing grade is $50 \%$, i.e. if a student obtains $50 \%$ out of total $100 \%$, he or she will pass the exam.

The data of both the pre-/posttests and that of the questionnaire were analyzed using the (SPSS) version 22 program. As mentioned above, posttest the midterm exam of the experimental and control groups. were collected to be analyzed.Each participant's grades regarding his/her performance on the four language skills (listening, speaking, reading and writing) in the midterm exam were computed into the SPSS version 22 program. An Independent samples t-test is "used when you want to compare the mean score of two different groups of people or conditions" (Pallant\& Manual, 2013, p. 247). An Independent samples t-test was employed to reveal the similarities and/or differences before and after the experiment.Data were presented using mean scores and standard deviations.

\section{Findings and Discussion \\ Effects of BLA}

To be able to answer the research question which aims at revealing the effects of the BLA on learning the language skills among second-year English as a foreign language (EFL) learners in Polytechnic University a pre and posttest were administered to the participants. Two groups were formed namely, experimental and control. A pretest was administered before the treatment phase and a post-test was administered after the treatment phase. Mean scores (M) and standard deviations (SD) were used to represent the performance of the participants in the experimental and control groups in both the pre and posttests.

Table 2 below outlines the results of both the pre and posttest of the experimental and control groups. From a general perspective, the results of the experimental group after the experiment showed significant improvement for all skills. For example, the mean score before the experiment for the listening skill was 10.00 which rose to 14.65 after that. In a similar fashion, the mean score of the speaking skill before the experiment was 10.05 which increased to 15.65 after the experiment. Similarly, regarding the reading skill (8.55 $\square$ 15.20) and the writing skill (12.05 $\square$ 19.95), the participants made progress. However, for the control group, there was a minor change for all skills. For example, the mean score rose from 9.95 to 10.45 for the listening skill, from 9.05 to 9.40 for the speaking skill, from 8.50 to 10.15 for the reading skill, and from 12 to 14.7 for the writing skill.

Table 2

BLA and the Listening Skill

\begin{tabular}{|c|c|c|c|c|c|c|c|}
\hline Groups & ${ }_{\text {est }}{ }^{T}$ & $\mathrm{~N}$ & $\mathrm{M}$ & SD & $\begin{array}{l}\text { t-test } \\
\text { (Independent) }\end{array}$ & d.f & $\begin{array}{l}\text { P- } \\
\text { Value } \\
\text { (sig) }\end{array}$ \\
\hline Experimenta & re $^{p}{ }_{\text {ost }}^{p}$ & $0^{2}$ & $\begin{array}{l}10.00 \\
14.65\end{array}$ & $\begin{array}{l}2.10 \\
2.56\end{array}$ & 6.74 & 19 & 0.00 \\
\hline Control & re ${ }_{\text {ost }}^{p}$ & $0^{2}$ & 10.45 & 2.08 & 0.93 & 19 & 0.36 \\
\hline
\end{tabular}


According to Table 2, with regard to the listening skill of the participants, it can be seen that the experimental group with a mean score of 10 (SD: 2.10) as compared to the control group M: 9.95, SD: 2.08 before the experiment. This shows that the participants started from the same language level or proficiency. On the other hand, after the experiment, there was a drastic improvement with regard to the listening skill with a mean score of 14.6 (SD: 2.5) in comparison to the control group which had a mean score of 10.45 (SD: 2.2). Moreover, according to the results $(\mathrm{df}=19$, at $\mathrm{p}<0.0 \%)$ the experimental group which underwent the BLA improved regarding the listening skill more in comparison to the control group which was exposed to a traditional method. These results show us that the BLA is very beneficial in developing EFL learners listening skills.

Table 3

BLA and the Speaking Skill

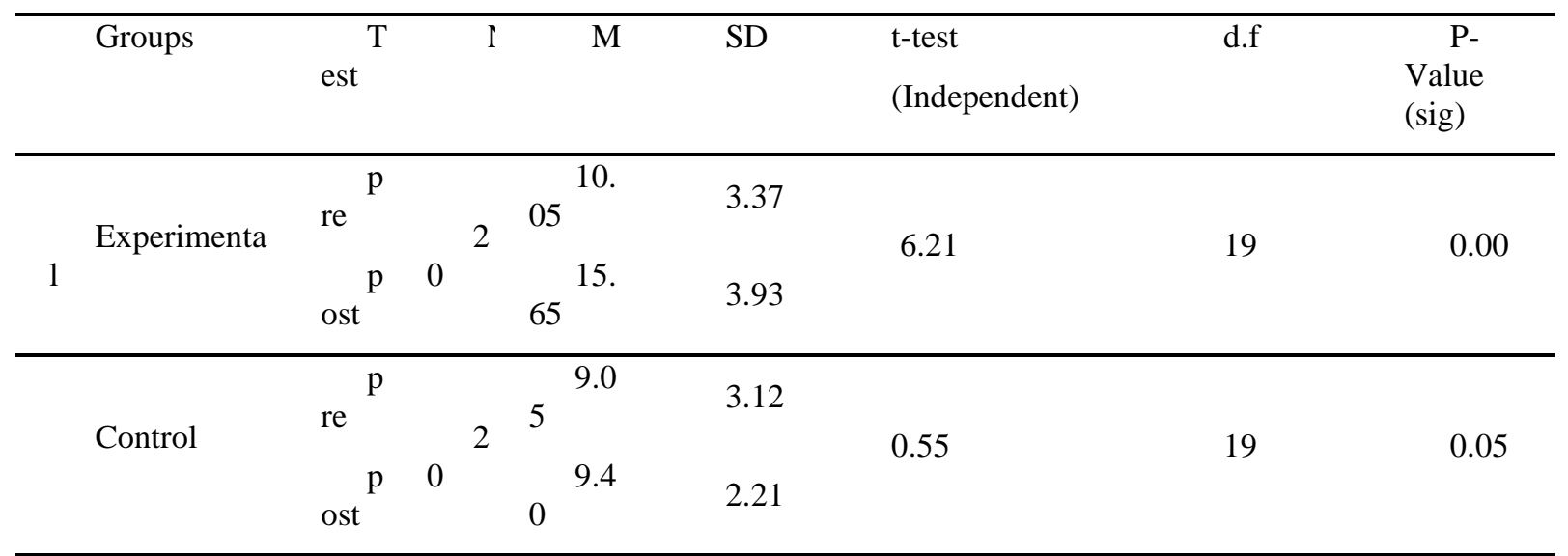

Table 3 illustrates the results regarding both the experimental and control groups with regard to the speaking skill. Prior to the experiment, it was revealed that the experimental group had a mean score of 10 (SD: 3.3) as compared to the control group (M: 9, SD: 3.12) in the pre-test. This shows that the participants started from the same language level or proficiency. On the other hand, after the treatment phase, the experimental group was seen to have dramatically improved with regard to the speaking skill with a mean score of 15.7 (SD: 3.9) as compared to the control group who achieved a mean score of 9.4 (SD: 2.2). It is evident from the results of the ttest $(\mathrm{df}=19$, at $\mathrm{p}<0.0 \%)$ that the group which underwent the BLA improved in terms of the speaking skills more than the control group which was exposed to a traditional method. The results show us that the BLA is highly effective in developing EFL learners speaking skills.

Table 4

The Results of the Reading Skill

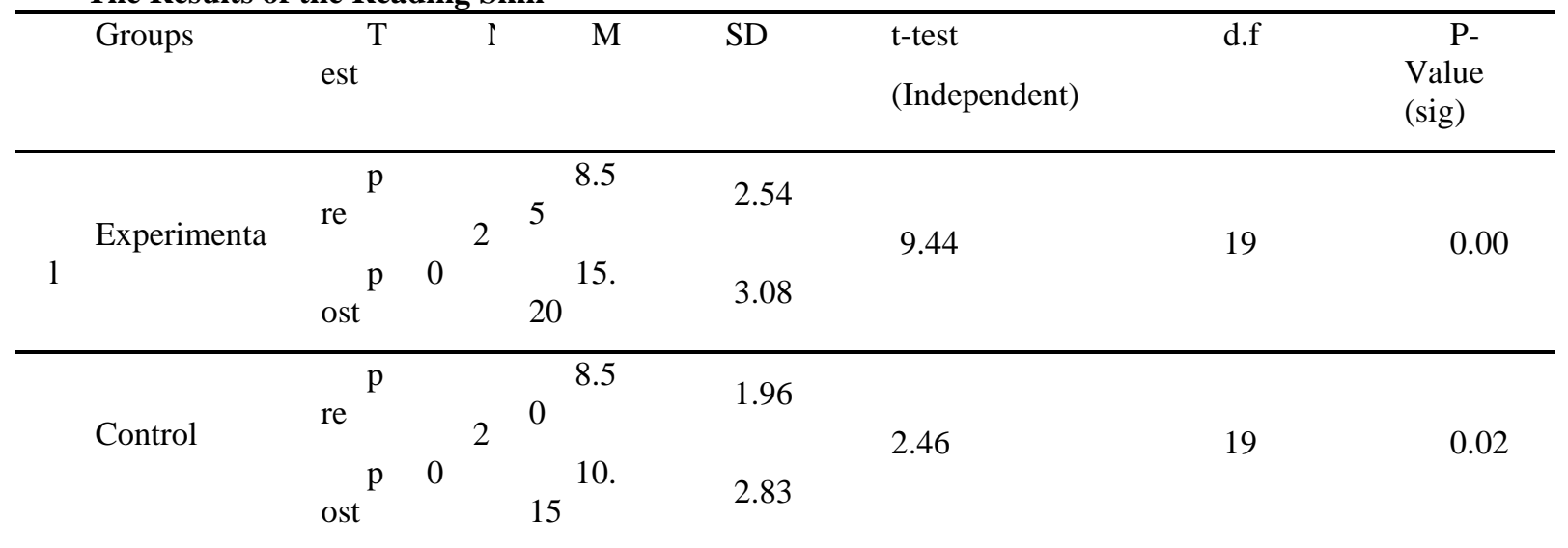

According to Table 4, as far as the reading skill is concerned, it can be seen that the experimental group had a mean score of 8.55 (SD: 2.5) as compared to the control group (M: 8.50, SD: 1.9) before starting the experiment. The indication of this is that the participants nearly started from the same language level or proficiency. On the other hand, after the experiment, there was a radical improvement of the scores of the experimental group with regard to the reading skill with a mean score of 15.2 (SD: 3 ) in comparison to the control group which had a mean score of 10.15 (SD: 2.8). Moreover, according to the results of the t-test $(\mathrm{df}=19$, at $\mathrm{p}<0.0 \%)$, the group which underwent the BLA improved regarding the reading skill more in comparison to the control group which was exposed to a traditional method. The results show us that the BLA is very effective in developing EFL learners reading skills

Table 5

\section{BLA and the Writing Skill}




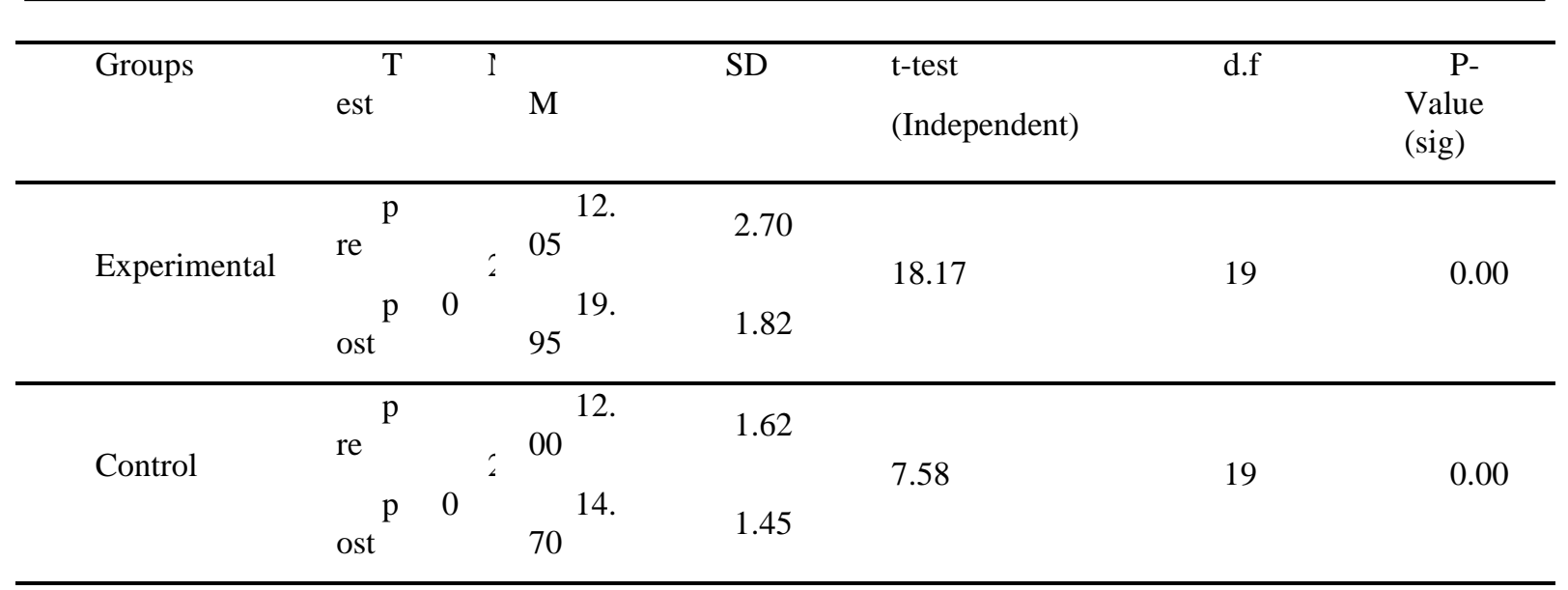

Regarding the writing skill, it can be seen that the experimental group had a mean score of 12.05 (SD: 2.7) as compared to the control group (M:12, SD:1.6) before starting the experiment. The indication of this is that the participants nearly started from the same language level or proficiency. On the other hand, after the experiment, there was a significant shift with the scores of the experimental group with regard to the writing skill with a mean score of 19.95 (SD: 1.8) in comparison to the control group which had a mean score of 14.45 (SD: 1.4). This shows that the group which underwent the BLA improved better regarding the writing skill more in comparison to the control group which was exposed to a traditional method. The results show us that the BLA is very effective in developing EFL learners writing skills.

Table 6

Total Results of pre and posttests for both groups

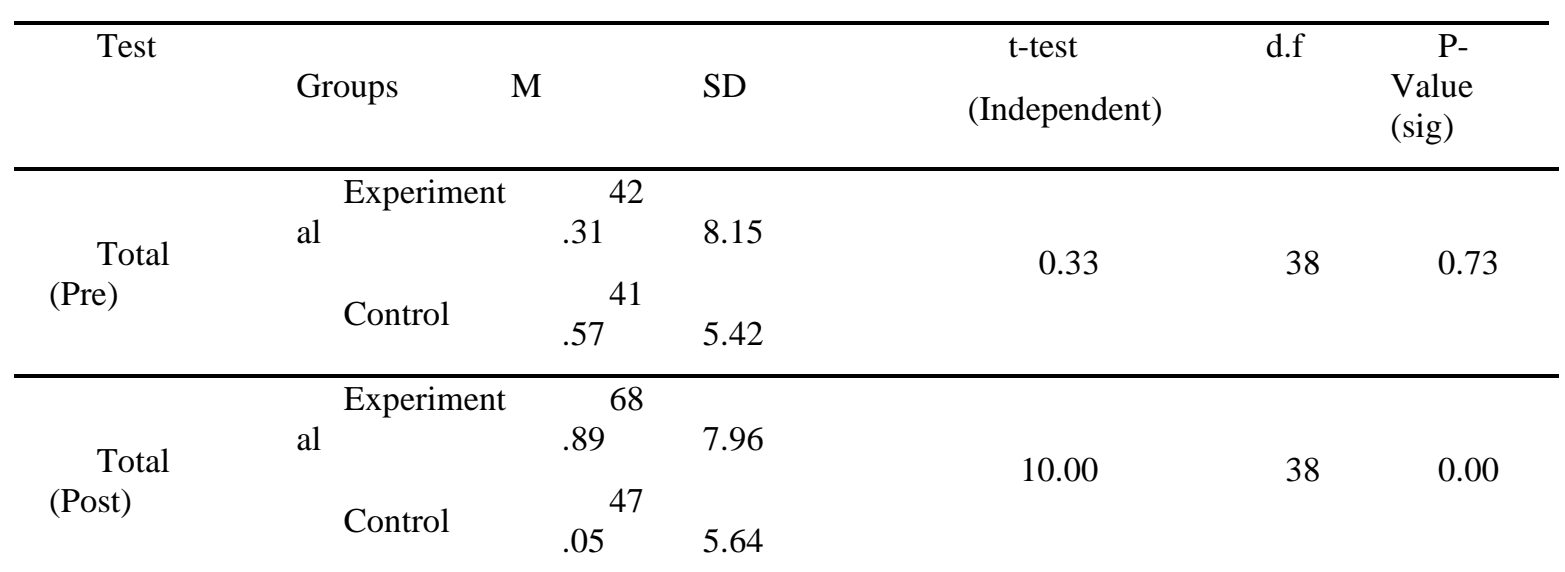

Regarding the results in Table 6, it can be seen that the experimental group had a mean score of 42.31(SD: 8.15) as compared to the control group (M: 41.57, SD: 5.42) before starting the experiment. This indicates that the participants nearly started from the same language level or proficiency. On the other hand, after the experiment, there was a significant shift with the scores of the experimental group with a mean score of 68.89 (SD: 7.96) in comparison to the control group which had a mean score of 47.05 (SD: 5.64). This shows that the group which underwent the BLA improved better regarding the four fundamental skills (listening, speaking, reading and writing) more in comparison to the control group which was exposed to a traditional method. The results show that the BLA is very effective in developing EFL learners' main skills (listening, speaking, reading and writing). It could be said that the results support a BLA when learning English. It is noticed from the results that the change in the mean of the posttest is significantly higher than that for the pretest.

\section{Conclusions}

The analysis of the findings and discussions of the results indicated that blended learning is an effective approach in teaching languages and in this case teaching the English language. It can be concluded, based on the findings of the study, that blended learning has a positive impact on the academic performance of learners. The blended learning approach (BLA) helped in improving the speaking, listening, writing and reading skills of the learners. Interestingly, both modes of teaching, i.e. with a BLA and traditional method, the participants of this study improved their four skills. However, when compared to the group that was taught with a BLA outperformed the group that was taught with a traditional method.

\section{References}

1. Adas, D., \&Bakir, A. (2013). Writing difficulties and new solutions: Blended learning as an approach to improve writing abilities. International Journal of Humanities and Social Science, 3(9), 254-266. 
2. Behjat, F., Yamini, M., \&Bagheri, M. S. (2012). Blended learning: A ubiquitous learning environment for reading comprehension. International Journal of English Linguistics, 2(1), 97-106. doi:10.5539/ijel.v2n1p97.

3. Bostancı, H. B., \&Çavuşoğlu, Ç. (2018). Pen-and-paper or online? An academic writing course to teachertrainees. Cogent Eduaction, 5(1), 1482606. https:// doi.org/10.1080/2331186X.2018. 1482606

4. Boumová, V. (2008). Traditional vs. modern teaching methods: Advantages and disadvantages of each (Doctoral dissertation, Masarykovauniverzita, Filozofickáfakulta).

5. Broadbent, J. (2017). Comparing online and blended learner's self-regulated learning strategies and academic performance. The Internet and Higher Education, 33, 24-31.

6. Brooks, M. G., \& Brooks, J. G. (1999). The courage to be constructivist. EducationalLeadership, 57 (3).

7. Caruso, M., Gadd Colombi, A., \& Tebbit, S. (2017). Teaching how to listen. Blended learning for the development and assessment of listening skills in a second language. Journal of University Teaching \& Learning Practice, 14(1), 14-18.

8. Cook, D. A., \&Artino, A. R. (2016). Motivation to learn: an overview of contemporary theories. Medical education, 50(10), 997-1014.doi: 10.1111/medu.13074

9. Dimitrios, B., Labros, S., Nikolaos, K., Maria, K., \& Athanasios, K. (2013). Traditional teaching methods Vs. teaching through the application of information and communication technologies in the accounting field: Quo Vadis? European Scientific Journal, ESJ, 9(28).

10. Dziuban, C. D., Hartman, J. L., \&Moskal, P. D. (2004). Blended learning. Educause Center for Applied Research Bulletin, 7(1), 12.

11. Etikan, I., Musa, S. A., \&Alkassim, R. S. (2016). Comparison of convenience sampling and purposive sampling. American journal of theoretical and applied statistics, 5(1), 1-4.doi: 10.11648/j.ajtas.20160501.11.

12. Fidaoui, D., Bahous, R., \& Bacha, N. N. (2010). CALL in Lebanese elementary ESL writing classrooms. Computer Assisted Language Learning, 23(2), 151-168. doi: org/ 10.1080/ 09588221003666248.

13. Fraenkel, J. R.., Wallen, E. Norman., \& Hyun, H., H. (2012). How to Design and Evaluate Research in Education. New York: McGraw.

14. Garrison, D. R., \&Kanuka, H. (2004). Blended learning: Uncovering its transformative potential in higher education. The internet and higher education, 7(2), 95-105.

15. Geta, M., \&Olango, M. (2016). The impact of blended learning in developing students' writing skills: Hawassa University in focus. African Educational Research Journal, 4(2), 49-68.

16. Ghahari, S., \&Ameri-Golestan, A. (2014). The effect of blended learning vs. classroom learning techniques on Iranian EFL learners' writing. International Journal of Foreign Language Teaching and Research, 1(3), 1-9.

17. Ghazizadeh, T., \&Fatemipour, H. (2017). The effect of blended learning on EFL learners' reading proficiency. Journal of Language Teaching and Research, 8(3), 606-614.doi: http://dx.doi.org/10.17507/jltr.0803.21

18. Gopalan, V., Bakar, J. A. A., Zulkifli, A. N., Alwi, A., \& Mat, R. C. (2017). A review of the motivation theories in learning. In AIP Conference Proceedings 1891(1), 020043.doi: 10.1063/1.5005376

19. Henrie, C. R., Bodily, R., Manwaring, K. C., \& Graham, C. R. (2015). Exploring intensive longitudinal measures of student engagement in blended learning. The International Review of Research in Open and Distributed Learning, 16(3),131-148.

20. http://cabinet.gov.krd/p/page $\cdot \operatorname{aspx} ? 1=12 \& \mathrm{~s}=050000 \& \mathrm{r}=308 \& \mathrm{p}=218 \mathrm{cabinet} \cdot$ gov $\cdot \mathrm{krd} / \mathrm{p} / \mathrm{p} \cdot \operatorname{aspx} ? \mathrm{l}=12 \& \mathrm{p}=2$ 16

21. https://epu.edu.iq/

22. Isiguzel, B. (2014). The blended learning environment on the foreign language learning process: A balance for motivation and achievement. Turkish Online Journal of Distance Education, 15(3).

23. Ituma, A. (2011). An evaluation of students' perceptions and engagement with e-learning components in a campus-based university. Active Learning in Higher Education, 12(1), 57-68.doi: 10.1177/1469787410387722

24. Jee, R. Y., \& O'Connor, G. (2014). Evaluating the impact of blended learning on performance and engagement of second language learners. International Journal of Advanced Corporate Learning, 7(3), $12-16$.

25. Kashefi, H., Ismail, Z., \&Yusof, Y. M. (2012). The impact of blended learning on communication skills and teamwork of engineering students in multivariable calculus. Procedia-Social and Behavioral Sciences, 56, 341-347.doi: 10.1016/j.sbspro. 2012.09.662

26. Kavaliauskienè, G. (2011). Blended learning in ESP listening. English for Specific Purposes World, 10 (31), 1-9.

27. Keshta, A. S., \&Harb, I. I. (2013). The effectiveness of a blended learning program on developing Palestinian tenth graders' English writing skills. Education Journal, 2(6), 208-221.doi: 10.11648/j.edu.20130206.12. 
28. Klimova, B. F. (2009). Modern information technologies in teaching foreign languages. Bulletin of the Transilvania University of Braşov,2(51),1-7.

29. Lim, D. H., \& Morris, M. L. (2009). Learner and instructional factors influencing learning outcomes within a blended learning environment. Journal of Educational Technology \& Society, 12(4), 282-293.

30. Liu, T. Y., \& Chu, Y. L. (2010). Using ubiquitous games in an English listening and speaking course: Impact on learning outcomes and motivation. Computers \& Education, 55(2), 630-643.doi: 10.1016/j.compedu.2010.02.023

31. Liu, W. Y., \& Cha, J. (2009). Motivation orientation in a Web-Based environment. Foreign Languages Research, 3, 121-123.

32. López-Pérez, M. V., Pérez-López, M. C., \& Rodríguez-Ariza, L. (2011). Blended learning in higher education: Students' perceptions and their relation to outcomes. Computers \& Education, 56(3), 818-826.

33. Luna, Y. M., \& Winters, S. A. (2017). "Why did you blend my learning?" A comparison of student success in lecture and blended learning introduction to sociology courses. Teaching Sociology, 45(2), 116-130.

34. Mak, B., \&Coniam, D. (2008). Using wikis to enhance and develop writing skills among secondary school students in Hong Kong. System, 36(3), 437-455. doi: 10.1016/j.system. 2008.02.004

35. Miyazoe, T., \& Anderson, T. (2010). Learning outcomes and students' perceptions of online writing: Simultaneous implementation of a forum, blog, and wiki in an EFL blended learning setting. System, 38(2), 185-199.doi: 10.1016/j.system.2010.03.006

36. Nazzal, N. (2014). Modern versus traditional teaching. Gulr News Education. Retrieved from https://gulfnews.com/news/uae/education/modern-vs-traditional- teaching-methods- 1.1418127.

37. Nielson, K., \& González-Lloret, M. (2010). Effective online foreign language courses: Theoretical framework and practical applications. The Eurocall Review, 17, 27-35.

38. Pallant, J., \& Manual, S. S. (2010). A step by step guide to data analysis using SPSS. Berkshire UK: McGraw-Hill Education.

39. Prince, M. J., \& Felder, R. M. (2006). Inductive teaching and learning methods: Definitions, comparisons, and research bases. Journal of Engineering Education, 95(2),123-138.

40. Sánchez N. \&Chavarro S. (2017). EFL Oral Skills Behavior when Implementing Blended Learning in a Content-SubjectTeachers' Professional Development Course. Colombian Applied Linguistics Journal, 19(2), 263-276.

41. Schechter, R., Macaruso, P., Kazakoff, E. R., \& Brooke, E. (2015). Exploration of a blended learning approach to reading instruction for low SES students in early elementary grades. Computers in the Schools, 32(3-4), 183-200.doi: 10.1080/07380569.2015. 1100652

42. Shih, R. C. (2010). Blended learning using video-based blogs: Public speaking for English as a second language students. Australasian Journal of Educational Technology, 26(6), 883-897.

43. Su,Y., Zheng, C., Liang, J. C., \& Tsai, C. C. (2018). Examining the relationship between English language learners' online self-regulation and their self-efficacy. Australasian Journal of Educational Technology, 34(3),105-121. doi: 10.14742/ajet.3548

44. Wahyuni, S. (2018). The Effect of Blended Learning Model towards Students' Writing Ability. Journal of English for Academic, 5(2), 97-111.doi: https://doi.org/10.25299/jshmic.

45. Wu, J. H., Tennyson, R. D., \& Hsia, T. L. (2010). A study of student satisfaction in a blended e-learning system environment. Computers \& Education, 55(1), 155-164. doi: 10.1016/j. compedu.2009.12.012

46. www.https://mhe-krg.org/node/1524

47. Yule, G. (2016). The study of language. Cambridge University Press. 7(2), 255-256.

48. Zarei, A. A., \& Abdi, V. (2016). Blended Learning, computer-based, and conventional reading Instruction affecting EFL learners' self-regulation and critical Thinking. International Journal of Humanities and Cultural Studies, 3(1), 2169-2187. 